\title{
Katarzyna Zalasińska
}

University of Warsaw

k.zalasinska@wpia.uw.edu.pl

ORCID: 0000-0003-2171-2560

https://doi.org/10.26881/gsp.2021.2.06

\section{Restrictions on the export of library materials from Poland}

\section{Introduction}

Library materials constitute a major element of documentary heritage. Resources gathered in libraries are collections not only of material carriers with historical, artistic, or scientific/scholarly value, but also important sources of information. This resource is protected principally by libraries acting as memory institutions and specialising in the conservation of library materials. The protection and conservation involved include assurance of the integrity of the resource, in particular through control of permanent export of it. This is because, in such cases, the item usually leaves the territory of Poland never to return, which involves an obligation for the respective authorities in charge of export control to analyse the value of library materials exported. This involves answering the question about the materials' importance to the Polish cultural heritage. This article is intended to evaluate the regulations governing permanent export applicable to library materials, considering the definition of library materials in the Act of 27 June 1997 on libraries (consolidated text: Journal of Laws of 2019, item 1479; hereinafter: LA). This article does not cover the export of library materials other than those belonging to heritage, which is regulated by art. 6a LA, whereby it has been assumed that library materials may be qualified not only as heritage, but also as cultural goods other than heritage. Apart from presenting the applicable regulation and discussing practical problems related to the application of it, this article also discusses the administrative procedures undertaken by The National Library of Poland with respect to the permanent export of library materials in the period 2015-2019. Conclusions on the research presented here are also compared to the results of bibliophile market analysis done by Paweł Podniesiński. This analysis has made it possible to formulate conclusions de lege lata and de lege ferenda. 


\section{Library materials as exported items}

\subsection{The definition of library materials in the Act of 27 June 1997 on libraries}

According to art. 5 LA, library materials include, in particular, documents containing recorded expression of human thought, intended for distribution irrespective of the physical carrier and method of recording, in particular: graphic (literary, cartographic, iconographic, and musical), audio, visual, audio-visual, and electronic documents. The regulations, however, do not define the term "document". The broad approach adopted in the Act of 1997 on libraries regulations requires reference to the definition of "document" adopted for the needs of the UNESCO Recommendation concerning the preservation of, and access to, documentary heritage including hat in digital form, 2015. ${ }^{1}$ For the purposes of the Recommendation, the definition was adopted that a document is an object comprising analogue or digital informational content and the carrier on which it resides. Furthermore, it is can be preserved and is usually moveable, while the content may consist of signs or codes (such as text), images (still or moving), and sounds, which can be copied or transferred. The carrier may have important aesthetic, cultural, or technical qualities, while the relationship between content and carrier may range from incidental to integral.

The term "library materials" was used in the previous Act of 9 April 1968 on libraries (Journal of Laws of 1968 No. 12, item 63) without, however, defining the term. Earlier regulations, namely the Decree of 17 April 1946 on libraries and preservation of library collections (Journal of Laws of 1946 No. 26, item 163) and care of library collections, stated that library collections shall mean all sorts of prints (books, magazines, brochures, etc.), manuscripts, maps, music scores, and drawings, as reading (utility) or heritage (museum) material. Specific resources of such materials form book collections. Earlier regulations, i.e., the Regulation of the President of 24 February 1928 on the National Library of Poland (Journal of Laws of 1928 No. 21, item 183), in art. 2, stated that the task of the National Library of Poland is to gather and keep the entire intellectual produce of the Polish nation, expressed in writing, print, or by any other mechanical or chemical means if the reference is to graphics, literature in foreign languages referring to the Polish nation, and literature in foreign languages necessary for the development of Polish intellectual life.

Literature points out that the definition of library materials was built pursuant to imprecise terms, which causes problems when applying legal regulations ${ }^{2}$. Furthermore, there are claims that the legislator makes this definition even more imprecise by editing the regulation, whereby "library materials include, in particular, [underlined by the author: K.Z.] documents containing (...)". As Jan Ciechorski rightly inter-

1 UNESCO Recommendation concerning the preservation of, and access to, documentary heritage including in digital form (2015), eds. A. Czajka et al., Warszawa 2016, p. 7, https://www.archiwa.gov.pl/files/ broszura_ZALECENIA_UNESCO.pdf (accessed: 10.05.2021).

2 Cf. K. Sikora, ,"Materiały biblioteczne a muzealia i zabytki. Kilka uwag o definicjach legalnych i ochronie prawnej", Toruńskie Studia Bibliologiczne 2017, no. 1(18), p. 132. 
prets this, the "formula applied in the regulation commented upon prevents precise separation of the designators of the term from other ones". ${ }^{3}$ Ciechorski presents a thesis that art. 5 LA does not constitute a strict definition, but is rather an interpretational guideline. ${ }^{4}$ This, however, means that pointing to what the term "library material" designates may prove exceedingly difficult in many cases.

\subsection{Library materials and monuments}

Establishing the meaning of the term "library materials" requires reference to other terms operating in the heritage conservation system. ${ }^{5}$ The fundamental term here is "monument" because of the "blanket" nature of the Act of 23 July 2003 on the protection and preservation of monuments (consolidated text: Journal of Laws of 2021, item 710). The Act, as stated in art. 2, covers conservation of all the items corresponding to the legal definition of a monument, unless special regulations provide otherwise. ${ }^{6}$

A mobile monument, in the meaning of art. 3 of the Act, includes mobile items, parts of them, or assemblies of mobile items, made by humans or related to human activities, and constituting evidence of a past era or an event, which should be kept in the interest of society because of historical, artistic, or scientific/scholarly value. Such an approach to the definition, namely by listing properties of items, means that it should be included in the model of a descriptive definition. ${ }^{7}$ This, thus, means that the term "monument" includes any items with specific properties. While referring exclusively to selected elements of the definition, something that is important to my discussion here, it is worth pointing to the indication that heritage must constitute evidence of a past era or a past event. As Alicja Jagielska-Burduk rightly points out, the term "past event" can be treated as a past event, but one that is not necessarily located in the distant past, whereas "past era" refers to a closed historical period ${ }^{8}$. Jan Pruszyński offers the interpretation that "art heritage is an item historically or culturally related through its style to a closed period or era" ${ }^{\prime \prime}$ Also, interpretation of the term "interest of society" proves problematic. Heritage, in fact, can only include items that must be kept in the social interest. The indicated general clause must be understood as the interest of the entire society or selected groups in it, not as a sum of individual interests, which it often collides with ${ }^{10}$.

\footnotetext{
3 J. Ciechorski, Ustawa o bibliotekach. Komentarz, Warszawa 2012, p. 21.

4 Ibidem, p. 21.

5 K. Sikora, "Od archiwaliów do dziedzictwa dokumentacyjnego. Profil najważniejszych pojęć prawnych" [in:] Ochrona dóbr kultury w rozwoju historycznym, ed. M. Różański, Olsztyn 2017, pp. 193-204.

6 K. Zalasińska, Ustawa o ochronie zabytków i opiece nad zabytkami. Komentarz, Warszawa 2020, p. 8.

7 A. Jagielska-Burduk, Zabytek ruchomy, Warszawa 2011, p. 69.

8 Ibidem, p. 70.

9 J. Pruszyński, Ochrona zabytków w Polsce. Geneza - organizacja - prawo, Warszawa 1989, p. 16.

10 K. Zalasińska, Ustawa o ochronie zabytków..., p. 14; cf. also: eadem, "Interes indywidualny a interes publiczny", Ochrona Zabytków 2008, no. 2, pp. 83-87.
} 
The definition was given detail in art. 6 para. 1 point 2e of the Act on the protection and preservation of monuments by adding a list, which states that mobile heritage may also include library materials referred to in art. 5 LA. It is worth pointing out that, in previous regulations of the Act of 15 February 1962 on the protection of monuments (consolidated text: Journal of Laws of 1999 No. 98, item 1150, as amended), in particular art. 5 para. 8 of this Act, the legislator provided a list of exemplary library materials. The regulation listed: manuscripts, autographs, illuminations, old prints, first prints, unique prints and other rarities, maps, plans, musical scores, drawings, other records of image or sound, instruments, and frames. Contrary to art. 6 para. 1 point 2e of the Act of 2003 on the protection and preservation of monuments, which only provides a reference to art. 5 LA, art. 5 of the Act of 1962 on the protection of monuments applicable until 2003 is more precise than art. 5 LA by providing an exemplary list of items to be qualified as library materials. It must, thus, be assumed that, in the present legal status, the legislator renders the definition of library materials much more imprecise as compared to earlier regulations. The avoidance of a precise definition of library materials by exemplary listing of the heritage categories that may be considered library materials, should undoubtedly be evaluated negatively.

\section{The procedure related to obtaining a permit for the permanent export of library materials}

When introducing a discussion of export regulations governing the permanent export of mobile heritage, it is worth pointing out that the legislator has divided such items into three categories: heritage covered by an export ban (art. 51 para. 4 Act of the protection and preservation of monuments ); heritage covered by the duty to obtain an export permit (art. 51 para. 1 of this Act); and heritage released from the duty to obtain an export permit (art. 59 of this Act). Heritage covered by an export ban includes the part of the National Library Resource that forms part of the Polish heritage (art. 51 para. 4 point 4 of the Act).

An export ban can also be a consequence of a refusal to grant a permit for permanent export. Pursuant to art. 52 para. 1a of the Act, the minister in charge of culture and national heritage conservation may refuse a one-off permit for the permanent export of an item of cultural property if the item is of special value to the country's cultural heritage. The regulation is applicable to the export of library materials. According to the practice adopted with respect to the export of items of heritage, an analysis of the special value of an item involves answering the following questions. Is the item specially related to the national heritage, whereby the very item, its authors, owners, or holders are related to the history of Poland and the life of its citizens? Does the item have special artistic value, and is it of special importance to a specific field of art, science/scholarship, or culture (an item of special value to the cultural heritage should have artistic, historical, and scientific/scholarly values making it globally or nationally 
representative of a given period, genre, or an artistic group, or it is a global or national precursor in stylistic, typological, or technical terms)? Can the export result in a loss to Polish collections? ${ }^{11}$

The lifting of an export ban under the law results in a situation where the duty to obtain the permit depends on the age and value of the item exported. For example, in the case of single books or collections of books, the duty refers to books that are over 100 years old and with a value exceeding PLN 6,000 (art. 51 para. 1 point 10). Items exempted from the duty to obtain a permit include both items below the age and value threshold stated in art. 51 para. 1 of the Act on the protection and preservation of monuments, as well as those listed in art. 59 of it. The catalogue of exemptions from a duty to obtain an export permit includes works by living authors that have not been inventoried by museums, or do not form part of the National Library Resource. The applicable regulations do not envisage exemptions related to library materials published after 9 May 1945, as referred to in art. 42 para. 1 point 4 of the Act on the protection and preservation of monuments. The regulations have, however, introduced a "rolling" time frame with respect to the categories of items referred to in art. 51 para. 1 of the act on heritage conservation and care of heritage. When evaluating current regulations as opposed to the legal status applicable until 2003, one must refer to the amendments introduced by the act of 18 March 2010 amending the Act on the protection and preservation of monuments, and changes in some other statutes. This is because library materials can be allocated to several categories listed in art. 51 para. 1 of the Act on heritage conservation and care of heritage. While referring to particular categories of items, considering the age and value of exported items, one must point at least to the possibility of allocating library materials to the category of "single manuscripts or collections of manuscripts" (items over fifty years old with a value higher than PLN 4,000 are exempt from the permit), "single books or collections of books" (items over 100 years old with a value higher than PLN 6,000 are exempt from the permit), or "single printed maps and music scores" (items over 150 years old with a value higher than PLN 6,000 are exempt from the permit). An analysis of the aforementioned regulations makes it possible to assume that regulations applicable until 2003 envisaged a broader catalogue of library materials not covered by export limitations. In particular, the regulations envisaged exemptions regardless of value, whereas, in most categories, the criterion of age seems to have been made more restrictive. It must be recalled that, at present, the two requirements must be met jointly; therefore, if a single book is 200 years old but its value remains below PLN 6,000, no export permit will be required.

While referring to an export ban, it must be pointed out that, pursuant to art. 58 of the Act on the protection and preservation of monuments, library materials are governed by limitations under art. 51 para. 4 of the Act, whereas the export ban related

11 The aspects analysed in the proceedings related to a permanent export permit have been drafted pursuant to the VoH (Value of Heritage) test by W. Szafrański. For more on this subject, see: W. Szafrański, A. Jagielska-Burduk, "Jednorazowe pozwolenie na stały wywóz zabytku za granicę z perspektywy kategorii wieku i wartości - ochrona dziedzictwa kulturowego a rynek sztuki w Polsce", Santander Art and Culture Law Review 2019, no. 1, pp. 93-94. 
to an item of library material may be caused by the fact that the item forms part of the National Library Resource or has been entered in the heritage register. It must be remembered that art. 11 of the Act instructs that the heritage register must not include items included in the World Heritage List, entered in a museum inventory, or forming part of the National Library Resource. If, therefore, an item of library material has not been covered by one of the aforementioned forms of conservation, it may be entered in the heritage register and, as a consequence, covered by an export ban. Entries to the mobile heritage register are made on the terms stipulated in art. 10 of the Act on the protection and preservation of monuments ..$^{12}$

Pursuant to art. 6 para. $1 \mathrm{LA}$, library collections of exceptional value and importance to the national heritage constitute, in whole or in part, the National Library Resource. At the same time, the legislator assumes that the National Library Resource is subject to special protection. The relevant literature indicates that library materials gathered within the National Library Resource include documents of special value. Dobrosława Platt assumes the resource to constitute a source of knowledge about the intellectual achievements of Poles, about the political history of the Polish nation, the history of the national culture and all its fields, as well as the development of national awareness, and Poles' participation in the growth of global civilisation ${ }^{13}$. Article 6 para. 2 LA, as referred to above, constitutes a certain axiological declaration without, however, any specific legal consequences ${ }^{14}$. The wording of such regulations indicates that only some library materials kept by libraries form part of the national heritage. This, thus, means that only a part of the activities pursued by such libraries can be qualified as national heritage conservation, ${ }^{15}$ a conclusion that I disagree with. At the same time, except for the export ban for library materials listed in the National Library Resource, Act of 1997 on libraries regulations does not introduce either a general or even a specific legal protection regime for any of the aforementioned groups of library materials. There is only a provision about their "special protection" (art. 6 para. 2 LA), which refers to physical protection only. ${ }^{16}$

Matters related to the export of heritage items are decided upon by the regional heritage conservator and the minister in charge of culture and national heritage conservation, who have the competences to issue permanent export permits. Pursuant to art. 58 of the Act on the protection and preservation of monuments, permits for per-

12 K. Sikora, “Materiały biblioteczne...," pp. 130-131.

13 D. Platt, "Zbiory biblioteczne a dziedzictwo kulturowe Polski - Narodowy Zasób Biblioteczny", Bibliotekarz 2007, no. 1, p. 6.

14 A similar provision functions in the regulations governing activities of museums: art. 13 of the Act of 21 November 1996 on museums (consolidated text: Journal of Laws of 2020, item 902) declares that "Register museums benefit from special protection", and art. 21(1) of the Act on museums insists that "museum collections constitute national goods".

15 Cf. L. Biliński, “Narodowy Zasób Biblioteczny - od koncepcji do realizacji”, Bibliotekarz 1999, no. 4, pp. 12-13.

${ }^{16}$ W. Kowalski, K. Zalasińska, „Prawo ochrony dziedzictwa kulturowego w Polsce - próba oceny i wnioski" [in:] System ochrony zabytków w Polsce - analiza, diagnoza, propozycje, ed. B. Szmygin, Lublin - Warszawa 2011, p. 26. 
manent and temporary export of library materials, as referred to in art. 51 para. 1 and art. 51 para. 3, are issued by the Director of the National Library of Poland. The legislator has envisaged that the regulations of art. 51 para. 1, art. 51 para. 2, art. 51 para. 4, art. 52 para. $1 \mathrm{a}$, and articles 53-57 apply accordingly. The Director of the National Library of Poland, within the terms of his/her statutory mandate, performs the tasks of the heritage conservation authorities. It can, therefore, be assumed that the legislator has made the Director of the National Library of Poland a functional authority of heritage conservation. Undoubtedly, decisions falling within the competences of the minister can be appealed and motions to repeat the procedure can be filed as stipulated in art. 127 para. 3 of the Act of 14 June 1960 - Code of Administrative Procedure (consolidated text: Journal of Laws of 2021, item 735).

It should be added that, in the aforementioned art. 58 of the Act on heritage conservation and care of heritage, for unknown reasons, the legislator makes reference to art. 51 para. 1, art. 51 para. 2, and art. 51 para. 4, while omitting art. 51 para. 3, which states that the items referred to in clauses 1 and 4 can be temporarily exported after obtaining a one-off permit for temporary export or a multiple individual permit for temporary export, or a multiple general permit for temporary export. At the same time, the regulation is decisive about the application of articles 53-57 of the Act, which govern the issue of the aforementioned temporary permits.

\section{The practical application of permits for the export of library materials that constitute heritage}

As indicated above, the Director of the National Library of Poland, within the terms of his/her statutory mandate as the authority in charge of heritage conservation, is the authority competent to decide about the permanent export of library materials. An examination of export files from administrative proceedings held in the period 2015-2019 indicates that the Director of the National Library of Poland issued just eight permits for permanent export in that period. The table below presents information on the number of permits for permanent export in particular years (additionally indicating when the export was outside the European Union), with additional information related to other export decisions issued in the same period for temporary export (a total of 54 permits for temporary export). Furthermore, one export proceeding was suspended in 2016 because of a justified suspicion that illegal export was being covered up by the permit application.

The analysis of the documentation regarding permanent export proceedings indicates that, while assessing whether library materials are of special value to cultural heritage, the Director of the National Library of Poland accounts for such aspects as: ownership marks testifying to the copy's belonging to any Polish collection of historical importance; the item's presence in public collections in Poland; and the importance and contents of the document from a scientific/scholarly perspective and in terms of 
Table 1. List of 2015-2019 export licenses

\begin{tabular}{|l|c|c|c|c|c|}
\hline & 2015 & 2016 & 2017 & 2018 & 2019 \\
\hline $\begin{array}{l}\text { Permit for a one-off } \\
\text { permanent export }\end{array}$ & 1 & $\begin{array}{c}(1-\text { sus- } \\
\text { pended } \\
\text { proceeding })\end{array}$ & 4 & $\begin{array}{c}1-\text { export } \\
\text { outside } \\
\text { the EU }\end{array}$ & 2 \\
\hline $\begin{array}{l}\text { Permit for one-off } \\
\text { temporary export }\end{array}$ & 9 & 11 & 12 & 5 & 5 \\
\hline $\begin{array}{l}\text { General permit for } \\
\text { multiple temporary } \\
\text { exports }\end{array}$ & 0 & 0 & 0 & 1 & 10 \\
\hline $\begin{array}{l}\text { General open per- } \\
\text { mit for temporary } \\
\text { export }\end{array}$ & 0 & 0 & 0 & $\begin{array}{c}1-\text { export } \\
\text { outside } \\
\text { the EU }\end{array}$ & 0 \\
\hline
\end{tabular}

Source: Own elaboration.

historical knowledge, which could be decisive in terms of the need to preserve the item in a Polish collection. It can, therefore, be assumed that, in the proceedings, the Director of the National Library of Poland applies the elements of inference that fall within the $\mathrm{VoH}$ (Value of Heritage) test referred to above. Here, I must point to one of the cases analysed, in which the justification of the export permit includes a statement that the analysed library material "constitutes heritage of high historical value, but it is not a unique item". This argumentation cannot be sustained because, in order to justify the attribution of special value to cultural heritage, it is sufficient to point to the high artistic value of an item. Any uniqueness of an item undoubtedly affects its value; yet the "threshold" to oblige the authority to consider refusing an export permit does not require the item to be characterised with this particular property (of uniqueness).

The statistics clearly show that permits for the permanent export of library materials are exceedingly rare. It would be worth referring the numbers to an analysis of the bibliophile market in the same period. A source of data here can be found in the analyses made by Paweł Podniesiński, ${ }^{17}$ an expert to the minister in charge of culture and national heritage conservation, who is also an expert regarding antiquarian publications. The value of the bibliophile market in the period 2015-2019 was estimated at PLN 7-9.5 million per year. In the same period, on average, 9,500 items were sold per year at bibliophile auctions. Market observations point to items traded that are of interest to collectors and buyers of non-Polish citizenship. At the same time, applications for permanent export are exceedingly rare and usually originate from renowned bibliophile antiquarians. It is clearly hard to judge whether or not the items bought at auctions by foreigners are then exported, but with some caution one may assume

17 Unpublished, courtesy of the Author. 
that, if export regulations were truly effective, one could expect more such applications. Perhaps, Regulation (EU) 2019/880 of the European Parliament and of the Council of 17 April 2019 on the introduction and the import of cultural goods (OJ L 151, 7.06.2019, pp. 1-14), which posits greater control of the legality of the flow of cultural goods, will be a factor affecting the increase in the number of the applications.

\section{Conclusions}

Library materials constitute a major element of Poland's cultural heritage. Documentary heritage gathered in libraries makes those libraries memory institutions entrusted with guarding resources of special value. Legal protection of library materials must be achieved through National Library Resources, as a form of protecting library materials of special value, but also through regulations governing the control of the export of library materials. What is particularly important here is the functioning of regulations governing the permanent export of heritage, because exported items constitute an irreversible loss to the heritage resources gathered on Polish territory. An analysis of export regulations related to library materials, as well as their application, makes it possible to entertain significant doubts as to the effectiveness of the adopted solutions. The imprecise object of protection raises doubt because of the formulation of the term "library materials". Another problem refers to the imprecise criteria that impose the duty to obtain a permit, and cover specific categories of items with an export ban. The applicable regulations, thus, require ordering and, principally, greater cohesion. In this respect, one should also reconsider a delimitation of legal orders: heritage - library materials - museum collections - archive materials - cultural goods. It is hard to justify creating a different export regime of, for example, manuscripts or old prints, depending on whether in any particular case they are treated as belonging to museum collections, archive materials, or library materials. It must, therefore, be assumed that the present legal status requires intervention from the legislator. Any changes should go towards overcoming the problem of fragmented legal orders related to heritage conservation by developing a coherent and holistic export regulation in the spirit of the UNESCO Recommendation from 2015.

\section{Literature}

Biliński L., "Narodowy Zasób Biblioteczny - od koncepcji do realizacji”, Bibliotekarz 1999, no. 4. Ciechorski J., Ustawa o bibliotekach. Komentarz, Warszawa 2012.

Czajka A., Kiliszek K., Komorowski T., Mrożek T., Woźniak W. (eds.), UNESCO Recommendation concerning the preservation of, and access to, documentary heritage including in digital form (2015), Warszawa 2016.

Jagielska-Burduk A., Zabytek ruchomy, Warszawa 2011. 
Kowalski W., Zalasińska K., „Prawo ochrony dziedzictwa kulturowego w Polsce - próba oceny i wnioski" [in:] System ochrony zabytków w Polsce - analiza, diagnoza, propozycje, ed. B. Szmygin, Lublin - Warszawa 2011.

Platt D., "Zbiory biblioteczne a dziedzictwo kulturowe Polski - Narodowy Zasób Biblioteczny", Bibliotekarz 2007, no. 1.

Pruszyński J., Ochrona zabytków w Polsce. Geneza - organizacja - prawo, Warszawa 1989.

Sikora K., "Materiały biblioteczne a muzealia i zabytki. Kilka uwag o definicjach legalnych i ochronie prawnej", Toruńskie Studia Bibliologiczne 2017, no. 1(18).

Sikora K., "Od archiwaliów do dziedzictwa dokumentacyjnego. Profil najważniejszych pojęć prawnych" [in:] Ochrona dóbr kultury w rozwoju historycznym, ed. M. Różański, Olsztyn 2017.

Szafrański W., Jagielska-Burduk A., "Jednorazowe pozwolenie na stały wywóz zabytku za granicę z perspektywy kategorii wieku i wartości - ochrona dziedzictwa kulturowego a rynek sztuki w Polsce", Santander Art and Culture Law Review 2019, no. 1.

Zalasińska K., "Interes indywidualny a interes publiczny", Ochrona Zabytków 2008, no. 2.

Zalasińska K., Ustawa o ochronie zabytków i opiece nad zabytkami. Komentarz, Warszawa 2020.

\section{Summary}

\section{Katarzyna Zalasińska}

\section{Restrictions on the export of library materials from Poland}

Library materials constitute a major element of Poland's cultural heritage. Documentary heritage gathered in libraries makes libraries memory institutions entrusted with guarding resources of special value. This article is intended to evaluate the regulations governing permanent export that are applicable to library materials, considering the definition of library materials in the Act of 27 June 1997 on libraries (consolidated text: Journal of Laws of 2019, item 1479). Statistics clearly show that permits for the permanent export of library materials are exceedingly rare. This article discuss the effectiveness of the adopted solutions concerning export regulations related to library materials.

Keywords: library materials, cultural heritage, export of cultural goods

\section{Streszczenie}

\section{Katarzyna Zalasińska}

\section{Ograniczenia w wywozie materiałów bibliotecznych z Polski}

Materiały biblioteczne stanowią ważny element polskiego dziedzictwa kulturowego. Ze względu na zgromadzone w bibliotekach dziedzictwo dokumentalne biblioteki są instytucjami pamięci, którym powierzono ochronę zasobów o szczególnej wartości. Celem artykułu jest ocena przepisów dotyczących stałego wywozu materiałów bibliotecznych, ze szczególnym uwzględnieniem definicji materiałów bibliotecznych zawartej w ustawie z dnia 27 czerwca 1997 r. o bibliotekach (tekst jedn.: Dz. U. z 2019 r., poz. 1479). Statystyki wyraźnie pokazują, że zezwolenia 
na stały wywóz materiałów bibliotecznych są niezwykle rzadkie. W artykule omówiono skuteczność przyjętych rozwiązań w zakresie regulacji wywozowych dotyczących materiałów bibliotecznych.

Słowa kluczowe: materiały biblioteczne, dziedzictwo kultury, wywóz dóbr kultury 